\title{
Relationship between Human Resource Disclosure and Company Attributes: An Empirical Study on Textile Companies in Bangladesh
}

\author{
Md. Hafij Ullah (Corresponding author) \\ Associate Professor, Department of Business Administration \\ International Islamic University Chittagong, Bangladesh \\ Mobile: +61470449084, Email: hafij_1980@yahoo.com
}

Md. Helal Uddin

Lecturer, Department of Business Administration

International Islamic University Chittagong, Bangladesh

Ruma Khanam

Senior Officer, Islami Bank Bangladesh Limited

CDA Avenue Branch, Muradpur, Chittagong, Bangladesh

Accepted: December 13, 2014

Doi:10.5296/ ijafr.v4i2.6708 URL: http://dx.doi.org/10.5296/ ijafr.v4i2.6708

\begin{abstract}
Human Resource (HR) disclosure in Textile companies in a developing country with abundance of human resources like Bangladesh is a new flavor in social accounting literature. The study is an investigation of HR disclosure practices and its relationship with the company specific attributes of all 29 listed Textile companies in Bangladesh. The study considered 81 human resource items under eight different classes which are expected to be disclosed in the annual report. The study found that though some graphs, charts and pictures were used for HR disclosure but most of the information was disclosed in narrative form. Sample companies on an average disclosed about $50 \%$ and about $60 \%$ companies disclosed less than $50 \%$ of the expected HR items and HR disclosure is significantly related with the size of the companies measured by gross revenue. The study expects that textile companies would disclose more HR information in future to attract more promising employees.
\end{abstract}

Keywords: Human Resource, Disclosure, Textile Companies, Bangladesh. 


\section{Introduction}

Human Resource is the key element of any organization and HR are the foremost vehicle in achieving the goals. Accountants have recognized the value of human assets for at least 70 years ago and in 1960s, Rensis Likert began the true human resource accounting research (Bowers, 1973). The main objective of HRA is to facilitate the effective and efficient management of human resources (Porwal, 1993). According to Sveiby (1997), human capital and structural capital concept are similar to other assets. Moore (2007) suggests that the value of human capital should be more fully considered when making decisions about the acquisition and disposal of people But the monetary value assumption of accounting does not allow reporting value of organization employees in organization's financial report because value of HR is difficult to measure in monetary value. As a result, though companies all over the world are showing their expenses related to human resources in the financial statements, they are not able to show the expertise of their 'Human Capital' and how these resources are utilized, in the financial statements. Therefore, stakeholders are being deprived of getting valuable information about the human resources of their organization (Hossain, et al., 2004).

Human capital reporting has received considerable academic and practitioner attention across the globe during the past decade and a half (Stewart, 1994; Abeysekera and Guthrie, 2004; Bassi et al., 2000).The corporations in the developed countries are usually disclose HR information in formal pattern in their annual report but in the developing countries like Bangladesh, HR disclosure aspect is very new concept and it is still in infant stage. Though it is not compulsory for the companies in Bangladesh, but they are making some HR disclosure voluntarily (Hossain, et al., 2004). There has been a scarcity of research on HR disclosure in the perspective of emerging economies (Khan \& Khan 2010). As the human resource has been considered as tactical capital, its accounting and disclosure aspects are becoming significant for the organizational success. So far our knowledge concern, no rigorous research work has been done on human resource reporting in annual report of textile companies in Bangladesh. Hence, this study is an attempt to investigate the HR reporting practices in the listed textile companies in Bangladesh and to evaluate the relationship between company attributes and HRD.

\section{Literature Review}

Human Resources (HR) is recognized as "human assets" (Likert, 1967), "human resources" (Brummet et al., 1968; Heckmian and Jones, 1967), "cultural capital" (Thompson, 1998), "worth of employees" (Roslender and Dyson, 1992), and HC (Liebowitz and Wright, 1999). The term 'Human Resource' was first used by Nobel Laureate, Theodore W. Schultz, in the 1961 American Economic Review Article, 'Investment in HC.' The term is now most frequently used to refer to a combination of skills, experience and knowledge. In 1968 Brummet, Flamholtz \& Pyle used the term "human resource accounting" for the first time. According to Schultz (1961), human Resource can be defined as abilities and skills of certain group of people or an individual person that have value. Embodied in this are behavior, experience, knowledge, morale and attitude, corporate culture to mention a few which when put together becomes of economic value to the organization. According to the American Association of Accountants as cited in Rao (2005) "Human Capital Accounting is a process of identifying and measuring data about human resources and communicating this to interested parties." It provides valuable information about human resource costs and values, serves to forward to decision making, and motivates decision makers to appropriate a human resource panorama (Sackmann et al., 1989). Research to examine the way in which human resource variables affect the efficiency of firms could be performed in a number of ways including analyzing the conjunction between different aspects of human resources and firm performance (Bassi, 1997). Looking at different proposals (Conner, 1991), the resource theory considers human resources in a more absolute way. This theory considers that the competitive position of a firm depends on its specific and not transcript assets. The most specific (and not transcript) asset that an enterprise has is its personnel. It takes boon of their interdependent knowledge. That would elucidate why some firms are more productive than others. With the same technology, a solid human resource team makes all the difference 
(Archel, 1995). There are two reasons for embodying human resources in accounting. First, people are a valuable resource to an organization so long as they perform services that can be quantified. Second, the value of a person as a resource depends on how he is engaged. So management style will also spell the human resource value (Ripoll and Labatut, 1994).

The study conducted by Ali et al. (2008) on Intellectual Capital (IC) disclosure practices of selected companies in Bangladesh using content analysis observed that companies disclose very limited IC items, including information on HR. The study of Khan and Ali (2010) on IC disclosure of Bangladeshi commercial banks reports the similar findings. A much older study conducted by Bala and Habib (1988) opined that separate financial reporting to employees is not mandatory in Bangladesh and thereby organizations disclosed only mandatory types of employee-related information, such as employee salaries and remuneration, provident fund, gratuity fund, welfare fund, festival bonuses, and other cash incentives based on employees annual performance, in accordance with the provision of Bangladesh Accounting Standard-19 "employees benefits" and the first schedule of The Income Tax Ordinance (1984) (Bala and Habib, 1988). Similarly, Hossain et al. (2004) reported that their sample of companies made few disclosures on HR information.

Although several researchers claim that better information about HR might produce considerable benefits, which might further assist the provision of more complete information to investors or potential investors (McGregor et al., 2004; Flamholtz and Main, 1999; Royal and O'Donnell, 2005, 2008), but the study of Wyatt (2001) of HR actually found that more human resource practices are not only associated with superior financial returns, they are also a principal sign of superior shareholder value.

The studies analysed above failed to address the wide range of HR reporting-related items. For example, while Hossain et al. (2004) consider 12 items to examine HR information, Ali et al. (2008) and Khan and Ali (2010) focus on only six items. The present paper thus differs from these studies in that it delineates a broader scope of HR information.

\section{Objectives of the Study}

The main objective of the study is to investigate the Human Resource Disclosure practices in textile companies in Bangladesh. The specific objectives of the study are:

a) To know about HR reporting practices in Annual reports of Textile sector in Bangladesh.

b) To know the extent of HR information reported in Annual report of textile sector in Bangladesh.

c) To justify whether there is any relationship between HR reporting and company specific attributes.

\section{Methodology of the Study}

\subsection{Data Sources}

The present study mainly used secondary data including the annual reports which have been collected from the websites of the sample textile companies and relevant literatures collected from different journals.

\subsection{Sample Selection}

The study considered all the 29 listed textile companies, that is, $100 \%$ of the population was considered for the present study.

\subsection{Choice of the Period}

The study used 2012 as the study period of which annual reports of the sample textile companies were taken as the basis of evaluating HR disclosure because of getting the contemporary picture of the textile companies. 


\subsection{Tools of analysis}

The analysis of data was done with the help of SSPS software version 19.0. Mean disclosure, percentage, cumulative percentage and correlation analysis were used for data analysis.

\subsection{Independent Variable and Hypotheses}

The study examined the association between the level of HR disclosure and size, age and profitability of the textile companies in Bangladesh. The independent variables and hypotheses development are as discussed below:

(a) Size: The independent variable size (measured by gross revenue) used in this study has been taken considering the previous studies performed by other researchers in case of disclosure studies. Many disclosure studies (e.g. Ullah, 2013; Uwalomwa, 2011; Hossain, 2010; Silva and Christensen, 2004; Spiegel and Yamori, 2004; Haniffa and Cooke, 2002; Ismail, 2002; Watson, et al., 2002; Inchausti, 1997; Hossain et al. 1995; Wallace and Naser, 1995; Raffournier, 1995; Ahmed and Nichollas, 1994; Cooke, 1991; Cooke, 1989; Wallace, 1987, Chow and Wong-Boren, 1987) suggest that there is a significant relationship between firm size and the extent of voluntary disclosure. However, other researchers (e.g. Ahmed, 2009; Hossain, et al., 2006; Sutthachai and Cooke, 2009 and Spero, 1979) found no significant relationship between size of the firm and level of disclosure.

\section{$H_{1}:$ There is no relationship between Size of the textile companies \{measured by $\left.G R\right\}$ and level of HR disclosure.}

(b) Age: Age of Textile companies here is the length of listing in capital market as a public limited company. Ullah (2013) found significant relationship between reporting information and age of the Islamic banks in Bangladesh. Ahmed (2009) also used age as an independent variable in disclosure study. As it is argued that older, well-established companies are likely to disclose more than newly established companies, the extent of a company's disclosure may be influenced by its age, i.e. stage of development and growth (Owusu-Ansah, 1998; Akhtaruddin, 2005). However, it is not possible to reach a conclusion that long-established textile companies can disclose more HR information than newly-established textile companies without justification. This leads to the following hypothesis:

$\mathrm{H}_{2}$ : There is no relationship between Age of the textile companies and level of HR disclosure.

(c) Profitability: The study took EPS as the measure of profitability of the textile companies in Bangladesh. Earlier studies of Ullah (2013), Ahmed (2009), Hossain (1998), Owusu-Ansah (1998), Inchausti (1997), Raffournier (1995); Wallace and Naser (1995) and Wallace (1987) used profitability in disclosure studies as independent variable. Hossain (1998) identified that profitability is capable of influencing the level of corporate information disclosure. Owusu-Ansah (1998) that unprofitable companies are also inclined to release more information to defend their poor performance. Lang and Lundholm (1993) noted that the influence of a company's profitability level on disclosure can be positive, neutral or negative, depending on its performance. But the study of Belkaoui and Kahl (1978) found a negative relationship between profitability and level of reporting. This leads to the following hypothesis:

$H_{3}:$ There is no relationship between Profitability of the textile companies \{measured by 
EPS\} and level of HR disclosure.

The multiple linear regression technique has been used to test the alternative hypotheses.

\subsection{The Dependent Variable}

The dependent variable used in the present study is HR Un-weighted Disclosure Index (HRDI) and the disclosure index has been calculated for each of the sample textile company under study. HRDI was developed based on a dichotomous procedure in which an item scores ' 1 ', if disclosed and ' 0 ' if do not disclosed a content of 81 items. Then total disclosed (HRDI) score for a textile company was calculated as additive as follows:

$$
\mathrm{HRDI}=\sum_{i=1}^{n} d i
$$

Where, $\mathrm{d}=1$ if the item $d_{i}$ is disclosed

0 if the item $d_{i}$ is not disclosed

$\mathrm{n}=$ number of items

\subsection{Content Analysis}

As content analysis is the most widely used method of research in Human Capital, Intellectual Capital, and CSR disclosure (Guthrie et al. 2004), hence the present study also used content analysis to attain its objective. Earlier studies on HR disclosure both in developed and developing countries also used annual reports as the main source of data (Absar, et al., 2012; Khan \& Khan 2010; Murthy \& Abeysekera 2007; Olsson 2001; Subbarao $\&$ Zeghal 1997). The study selected 81 expected human resource disclosure items classified into 8 categories - such as Basic HR items (13), HR policy items (10), HR financial items (20), HR importance to organization items (6), HR Health and Safety items (6), HR development items (8), HR relationship and culture items (13), and HR others items (5). The selected 81 items were collected from IAS-19 of employee benefit, annual report of different companies and research papers namely Hossain (2008); Shirley et al. (2009); Hossain, et al., (2004); Mamun (2009); Alam \& Deb (2010); Li, Pike \& Haniffa (2006); Islam \& Deegan (2010); Agca \& Onder (2007) and others.

\subsection{Multiple Regression Model}

The study evaluated the relationship between HR disclosure and industry specific attributes of the textile company using the following multiple regression model:

$\mathrm{HRDI}=\alpha+\beta 1 \mathrm{GR}+\beta 2 \mathrm{AGE}+\beta 3 \mathrm{EPS}+\epsilon_{\mathrm{i}}$

Where HRDI = Human Resource disclosure score;

$\mathrm{GR}=$ Gross Revenue

AGE $=$ Age of the sample as listed Company

EPS $=$ Earnings Per Share

$\alpha=$ the constant, and

$\epsilon_{\mathrm{i}}=$ the error term 


\section{MlMacrothink}

International Journal of Accounting and Financial Reporting

ISSN 2162-3082

2014, Vol. 4, No. 2

\section{Findings and Analysis}

\subsection{Ways of HR Disclosure}

Disclosure may take different forms like narrative expression, charts, graphs and pictures. Textile companies in Bangladesh disclosed HR information in 2012 in different ways which are discussed as under:

\section{(a) Words}

Most of the textile companies expressed HR information in narrative form. On an average 1101.72 words were used for HR disclosure where minimum 365 words and maximum 3607 words. It is observed that $27.30 \%$ of the companies used less than 500 words, $34 \%$ of the companies used 501 to 1000 words and $10.20 \%$ of the companies used more than 2500 words for HR disclosure purpose.

\section{(b) Sentences}

Textile companies used significant amount of sentences in disclosing HR information though it is not mandatory for them. On an average 54.38 sentences were used where minimum 32 sentences and maximum 127 sentences were used for this purpose. About $70 \%$ of the companies used less than 60 sentences and $20.40 \%$ of the companies used 60 to 90 sentences in HR disclosure.

\section{(c) Charts}

Textile companies in Bangladesh used different charts for HR disclosure. On an average they used two charts where minimum zero and maximum 14 charts were used. The data revealed that one-quarter of the companies used no chart and another quarter used only one chart and more than $41 \%$ companies used two charts for HR disclosure purpose.

Table No. 1: Words, Sentences, Graphs, Charts \& Pictures used for HR reporting

\begin{tabular}{|l|l|l|l|l|l|}
\hline & Word & Sentence & Chart & Graph & Picture \\
\hline Mean & 1101.72 & 54.38 & 1.83 & .72 & 1.76 \\
\hline $\begin{array}{l}\text { Std. } \\
\text { Deviation }\end{array}$ & 8.97 & 24.45 & 2.58 & 1.22 & 3.69 \\
\hline Variance & 8.05 & 597.67 & 6.65 & 1.49 & 13.82 \\
\hline Minimum & 365.00 & 32.00 & .00 & .00 & .00 \\
\hline Maximum & $\mathbf{3 6 0 7 . 0}$ & $\mathbf{1 2 7 . 0 0}$ & $\mathbf{1 4 . 0 0}$ & $\mathbf{5 . 0 0}$ & $\mathbf{1 6 . 0 0}$ \\
\hline
\end{tabular}

Source: Developed by Authors

\section{(d) Graphs}

Textile companies also used graphs in disclosing the trends in HR and other HR information in annual report. On an average they used one graph where minimum is zero and maximum is 5. The noticeable findings in this case is that more than $62 \%$ of the companies used no graphs, more than $20 \%$ companies used one and remaining companies used more than 2 graphs. 
(e) Pictures

HR information was also disclosed in the annual report using pictures. The data show that one an average 2 picture were used for this purpose where minimum zero and maximum 16 pictures were used. Most importantly two-thirds of the companies used no picture and about $14 \%$ of the companies used 2 pictures.

\subsection{Heading-Wise HR Disclosure}

\section{(a) HR Basic}

In total 13 basic HR information was considered in the study, on an average Textile companies disclosed $48.81 \%$ of these items. Among the companies, minimum basic information disclosure is $30.77 \%$ and maximum disclosure is $84.62 \%$ of the basic HR information. About $14 \%$ of the companies disclosed one-third and about $40 \%$ of the companies disclosed two-thirds of the basic HR information.

\section{(b) HR Policies}

Ten HR policy items were considered for the study out of which textile companies on an average disclosed about $60 \%$ of the policy information, minimum $40 \%$ and maximum $80 \%$. Among the companies, $44.80 \%$ disclosed less than $50 \%$ and one $34.40 \%$ of the companies disclosed more than $70 \%$ of HR policy information.

\section{(c) HR Financial}

The content analysis of HR information of the study consist maximum 20 items relating to financial information of HR. On an average textile companies disclosed $52.76 \%$ of financial items where minimum 35\% and maximum 75\%. Among the companies $34.40 \%$ disclosed less than $50 \%$ and one-third of them disclosed more than $60 \%$ of HR financial items.

\section{(d) HR Importance to Organization}

Only 6 items were taken relating to HR importance to organization for the study. It is observed that maximum $60 \%$ of the items on an average disclosed where $33.33 \%$ is the minimum and $83.33 \%$ is the maximum. About $55 \%$ of the companies disclosed less that $50 \%$ and about $14 \%$ disclosed more than $83 \%$ of items of HR importance to organization.

\section{(e) HR Health and Safety}

Similarly, six items were also considered relating to HR health and safety. The data revealed that companies disclosed more than $50 \%$ on an average where minimum is $16.67 \%$ and maximum is $83.33 \%$. One-third of the companies disclosed less than one-third and about $35 \%$ of them disclosed two-third of HR health and safety related information in annual report.

\section{(f) HR Development}

In total 8 items relating to HR development taken into account in this study. On an average Textile companies disclosed about $57 \%$ of HR development items where minimum is $37.50 \%$ and maximum is $87.50 \%$. Data revealed that more than $50 \%$ companies disclosed less than $50 \%$ and $31 \%$ of them disclosed less than two-third of HR development items.

\section{(g) HR Relations and Culture}

Out of 13 items of information in HR relationship and culture, on an average $46.68 \%$ of the items were disclosed by the Textile companies in Bangladesh in their annual report. Minimum disclosure is $30.77 \%$ and maximum disclosure is $69.23 \%$ on HR relation and culture. Among the companies, $31 \%$ of them disclosed the lowest level of $30.77 \%, 62 \%$ of them disclosed less than $50 \%$ items and only $17.20 \%$ of them disclosed two-third of the selected items. 


\section{Macrothink}

International Journal of Accounting and Financial Reporting

ISSN 2162-3082

(h) HR Other items

Finally, other HR items consists of only 5 items out of which textile companies in Bangladesh on an average disclosed only $16.55 \%$ where minimum disclosure level is zero percent and maximum is only $40 \%$. It is observed that more than $40 \%$ companies disclosed no information, about $35 \%$ disclosed only $20 \%$ and one quarter of them disclosed $40 \%$ of the other HR information.

Table No: 2 Heading-wise HR disclosure in textile sector in Bangladesh

\begin{tabular}{|l|l|l|l|l|l|l|l|l|l|}
\hline & $\begin{array}{l}\text { HR } \\
\text { Basic }\end{array}$ & $\begin{array}{l}\text { HR } \\
\text { Policy }\end{array}$ & $\begin{array}{l}\text { HR } \\
\text { Fin }\end{array}$ & $\begin{array}{l}\text { HR } \\
\text { Imp. }\end{array}$ & $\begin{array}{l}\text { HR } \\
\text { H\& S }\end{array}$ & $\begin{array}{l}\text { HR } \\
\text { Develop. }\end{array}$ & $\begin{array}{l}\text { HR } \\
\text { Rela. }\end{array}$ & $\begin{array}{l}\text { HR } \\
\text { Other }\end{array}$ & $\begin{array}{l}\text { Total } \\
\text { Disclosure }\end{array}$ \\
\hline Mean & 48.81 & 58.97 & 52.76 & 58.05 & 51.15 & 56.90 & 46.68 & 16.55 & 49.98 \\
\hline Std.Deviation & 14.29 & 12.05 & 1.15 & 14.52 & 16.02 & 1.27 & 14.53 & 16.10 & 8.80 \\
\hline Variance & 204.07 & 145.32 & 133.19 & 210.74 & 256.62 & 162.79 & 211.04 & 259.11 & 77.36 \\
\hline Minimum & 30.77 & 40.00 & 35.00 & 33.33 & 16.67 & 37.50 & 30.77 & .00 & 39.51 \\
\hline Maximum & 84.62 & 80.00 & 75.00 & 83.33 & 83.33 & 87.50 & 69.23 & 40.00 & 67.90 \\
\hline
\end{tabular}

Source: Developed by Authors

\subsection{Total HR Disclosure}

Among the total 81 items of HR information considered for the study, on an average the Textile companies in Bangladesh disclosed almost $50 \%$ of them in the annual report. Minimum level of total disclosure level is about $40 \%$ and maximum is two-third of the selected total items under study. It is evident that about $58.30 \%$ of the companies disclosed less than $50 \%$ of expected disclosure, $20.50 \%$ of the companies disclosed $50 \%$ to $60 \%$ and $20.60 \%$ of the companies disclosed $60 \%-70 \%$ HR information in annual report.

Graph No. 1: showing total HR disclosure level of Textile Co. in annual report

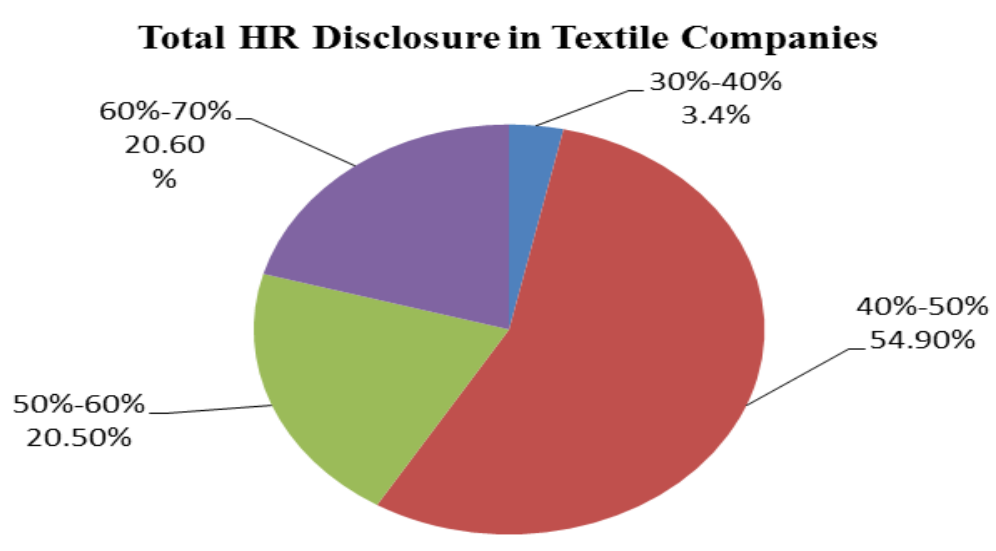

Source: Developed by Authors 


\section{Macrothink}

International Journal of Accounting and Financial Reporting

ISSN 2162-3082

2014, Vol. 4, No. 2

\subsection{Ranking of the Textile Companies}

Table below shows the ranking of the Textile companies based on total HR disclosure. It is found that Generation Next Fashions Ltd. Ranked $1^{\text {st }}$ which disclosed the highest $55(67.90 \%)$ HR information, Tallu Spinning Ltd. Ranked $2^{\text {nd }}$ which disclosed $53(65.43 \%)$ whereas Mitun Knitting Ltd. Ranked the last $16^{\text {th }}$ position which disclosed only $32(39.51 \%)$ items of HR information in annual report.

Table No. 3: Ranking of sample on the basis of total HR disclosure

\begin{tabular}{|c|c|c|c|}
\hline SI No. & Textile Companies & Total Disclosure & Ranking \\
\hline 1 & Generation Next Fashions Ltd. & 67.90 & 1 \\
\hline 2 & Tallu Spinning Ltd. & 65.43 & 2 \\
\hline 3 & $\begin{array}{l}\text { The Dacca Dyeing \& Manufacturing } \\
\text { Co. Ltd. }\end{array}$ & 64.2 & 3 \\
\hline 4 & R.N. Spinning Mills Ltd. & 64.2 & 3 \\
\hline 5 & Square Textile Ltd. & 64.2 & 3 \\
\hline 6 & Argon Denims Ltd. & 62.96 & 4 \\
\hline 7 & Rahim Textile Ltd. & 55.56 & 5 \\
\hline 8 & Sonargaon Textile Ltd. & 55.56 & 5 \\
\hline 9 & Zahin tex Industries Ltd. & 51.85 & 6 \\
\hline 10 & CMC Kamal Ltd. & 50.62 & 7 \\
\hline 11 & Modern Dyeing \& Screen Printing Ltd. & 50.62 & 7 \\
\hline 12 & Safko Spinning Ltd. & 50.62 & 7 \\
\hline 13 & AllTex Industries Ltd. & 49.38 & 8 \\
\hline 14 & Anlimayarn Deying Ltd. & 46.91 & 9 \\
\hline 15 & Delta Spinners Ltd. & 46.91 & 9 \\
\hline 16 & Saiham Cotton Mills Ltd. & 46.91 & 9 \\
\hline 17 & Desh Garments Ltd. & 45.68 & 10 \\
\hline 18 & Dulamia Cotton Ltd. & 45.68 & 11 \\
\hline
\end{tabular}




\begin{tabular}{|llcc}
\hline 19 & Envoy Textiles Ltd. & 45.68 & 11 \\
\hline 20 & Al-Haj Textile Ltd. & 44.44 & 12 \\
\hline 21 & Malek Spinning Mills Ltd. & 43.21 & 13 \\
\hline 22 & Saiham Textile Ltd. & 43.21 & 13 \\
\hline 23 & Apex Spining \& Knitting Mills Ltd. & 41.98 & 14 \\
\hline 24 & Maksons Spinning Mills Ltd. & 41.98 & 14 \\
\hline 25 & Metro Spinning Ltd. & 41.98 & 15 \\
\hline 26 & H.R. Textile Ltd. & 40.74 & 15 \\
\hline 27 & Prime Textile Ltd. & 40.74 & 15 \\
\hline 28 & Stylecraft Textile Ltd. & 40.74 & 16
\end{tabular}

\section{Source: Developed by Authors}

\subsection{HR Information disclosed by all Textile Companies}

Table No. 4: HR Information disclosed by all Textile Companies

\begin{tabular}{|l|l|}
\hline HR policies: & $\begin{array}{l}\text { Basic HR Information: } \\
\text { Policy of Reward } \\
\text { Policy of Recruitment } \\
\text { category (average) numbers employed by } \\
\text { Employee Capability }\end{array}$ \\
\hline $\begin{array}{l}\text { Financial Information on HR: } \\
\text { Statutory wages (salaries) } \\
\text { Awards \& rewards for good } \\
\text { performance } \\
\text { Cost \& Safety measures }\end{array}$ & $\begin{array}{l}\text { HR Development: } \\
\text { Employee career development } \\
\text { Employee Productivity } \\
\text { Fevelopment of Human Resource } \\
\text { HR Relationship \& Culture: } \\
\text { Employee Behavior }\end{array}$ \\
$\begin{array}{l}\text { Employee Teamwork } \\
\text { Employee Turnover }\end{array}$ & \\
\hline
\end{tabular}




\subsection{HR Information not disclosed by any Textile Companies}

Table No. 5: HR Information not disclosed by any Textile Companies

\begin{tabular}{|l|l|}
\hline Basic HR Information: & HR policies: \\
Geographical distribution of employees & $\begin{array}{l}\text { Policy towards Employment of disabled } \\
\text { persons }\end{array}$ \\
\hline $\begin{array}{l}\text { HR importance to organization: } \\
\begin{array}{l}\text { Action with respect to informing } \\
\text { employees, consulting employees, } \\
\text { encouraging (and engaging in) } \\
\text { employee participation } \\
\text { communication and }\end{array}\end{array}$ & $\begin{array}{l}\text { Health and safety at work: } \\
\text { Toxic hazards (e. g.) to employees and } \\
\text { on accidents }\end{array}$ \\
\hline $\begin{array}{l}\text { HR Relationship \& Culture: } \\
\text { Union activity }\end{array}$ & \\
\hline
\end{tabular}

\subsection{Relationship between Corporate Attributes and HR Disclosure}

As HR disclosure is not mandatory for the Textile companies in Bangladesh, therefore, getting a relationship between corporate attributes and HR disclosure is unlikely. The study tried to find whether there is any relationship between HR disclosure and size (measured by GR), age and profitability (measured by EPS). The study found a significant relationship between HR disclosure and size (measured by GR) of the Textile companies in Bangladesh.

Table No. 6: Showing Relationship between Corporate Attributes and HR Disclosure

\begin{tabular}{|c|c|c|c|c|c|}
\hline \multicolumn{6}{|c|}{ Correlation Matrix } \\
\hline & & $\begin{array}{l}\text { Total_Disc } \\
\text { lo }\end{array}$ & $\begin{array}{l}\text { Log_G } \\
\mathrm{R}\end{array}$ & Age & EPS \\
\hline \multirow{3}{*}{$\begin{array}{l}\text { Total_Disc } \\
\text { lo }\end{array}$} & $\begin{array}{l}\text { Pearson } \\
\text { Correlation }\end{array}$ & 1.000 & & & \\
\hline & Sig. (2-tailed) & .000 & & & \\
\hline & $\mathrm{N}$ & 29 & & & \\
\hline \multirow{3}{*}{ Log_GR } & $\begin{array}{l}\text { Pearson } \\
\text { Correlation }\end{array}$ & $.433 *$ & 1.000 & & \\
\hline & Sig. (2-tailed) & .019 & .000 & & \\
\hline & $\mathrm{N}$ & 29 & 29 & & \\
\hline
\end{tabular}




\begin{tabular}{|l|l|l|l|l|l|}
\hline \multirow{4}{*}{ Age } & $\begin{array}{l}\text { Pearson } \\
\text { Correlation }\end{array}$ & .064 & -.268 & 1.000 & \\
\cline { 2 - 7 } & Sig. (2-tailed) & .742 & .160 & .000 & \\
\cline { 2 - 7 } & $\mathrm{N}$ & 29 & 29 & 29 & \\
\hline \multirow{4}{*}{ EPS } & $\begin{array}{l}\text { Pearson } \\
\text { Correlation }\end{array}$ & .243 & .147 & -.130 & 1.000 \\
\cline { 2 - 7 } & Sig. (2-tailed) & .205 & .446 & .501 & .000 \\
\cline { 2 - 7 } & $\mathrm{N}$ & 29 & 29 & 29 & 29 \\
\hline $\begin{array}{l}* \\
\text { (2-tailed). }\end{array}$ \\
$\begin{array}{l}* * \text { Correlation is significant at the } \\
\text { (2-tailed). }\end{array}$ \\
\hline
\end{tabular}

\section{Source: Developed by Authors}

\section{Conclusion}

As a voluntary disclosure area of HR information in the annual report, he study observed that Textile companies in Bangladesh on an average disclosed about 50\% of the listed expected information. The sample companies disclosed HR information satisfactorily using sufficient number of words and sentences, but the use of charts, Graphs and pictures are not considered sufficient for maximum companies. Moreover, all textile companies disclosed HR information in income statement and notes to the financial statement. As there is no standard guideline in this regard, most of the textile companies didn't disclose HR information in annual report properly. The significant relationship between size measured by gross revenue and HR information disclosure signifies that the larger the textile company the higher the amount of HR disclosure in annual report.

The study expects that textile companies would disclose more HR information in their annual report to attract more promising employees in their textiles. They may use more charts, pictures and Graphs to disclose HR Information, because these are more helpful in easy understanding the scenario than linguistic presentation. Similarly, not only government but also other regulatory authorities like DSE, SEC, Company Registrar etc. may encourage more disclosure of $\mathrm{HR}$ information to help textile companies creating a favorable job environment in these industries.

The results of the study cannot be used unanimously because the results of other study may be different if a different data set, different sample, or different methodology is used. In using the result of the study, the limitations (such as, data is of a single year and the study is on a textile sector only) should be considered carefully.

\section{References}

Abeysekera, I. and Guthrie, J. (2004), "Human capital reporting in a developing nation", The British Accounting Review, Vol. 36, pp. 251-268. 
Absar, M.M.N., Orazalin, N.S. \& Mahmood, M., (2012), 'Human capital reporting in emerging economies: a comparative study on the banking sectors of Bangladesh and Kazakhstan, Journal of Academy of Business and Economics, ISSN: 1542-8710, Vol. 12, No. 3, Accession Number: 312015162

Agca, A. and Onder, S. (2007), Voluntary Disclosure in Turkey: A Study on Firms Listed in Istanbul Stock Exchange (ISE), Problems and Perspectives in Management, Volume 5, Issue 3, pp. 241-250.

Ahmed, A.A., (2009), Compliance of Financial Disclosure in Corporate Annual Reports of Banking Sector in Bangladesh, Unpublished PhD Dissertation, University of Rajshahi, Bangladesh.

Ahmed and Nicholls (1994), The impact of Non-financial Company Characteristics on Mandatory Compliance in Developing Countries: The Case of Bangladesh, The International Journal of Accounting, Vol. 29, No. 1, pp. 60-77.

Akhtaruddin, M. (2005), 'Corporate Mandatory Disclosure Practices in Bangladesh', International Journal of Accounting, Vol. 40, pp. 399-422.

Alam, I. \& Deb, S.K., (2010), 'Human Resource Accounting Disclosure (HRAD) In Bangladesh: Multifactor Regression Analysis - A Decisive Tool of Quality Assessment', The Cost and Management, May-June, pp. 9-13.

Ali, M.M., Khan, M.H.U.Z. and Fatima, J.K. (2008), "Intellectual capital reporting practices: evidence from Bangladesh", Dhaka University Journal of Business Studies, Vol. 29 No. 1, pp. 23-45.

Archel (1995) "Activos intangibles: análisis de lagunas partidas polémicas," Revista técnica del Instituto de Censores Jurados de Cuentas de España, 7.

Bala, S.K. and Habib, A. (1988), "Financial reporting to employees - Bangladesh case", Dhaka University Journal of Business Studies, Vol. 19 No. 1, pp. 215-36.

Bassi, L. J., Benson, Van Buren, G. S., and Bugarin, R. (1997) "Human Performance Practices Report". Alexandria, VA: American Society for Training and Development

Bassi, L.J., Lev,B., Low, J., McMurrer, D.P. and Siesfeld, G.A. (2000), "Measuring corporate investments in human capital", in Blair, M.M. and Kochan, T.A. (Eds), The New Relationship, Human Capital in the American Corporation, Brookings Institution, Washington, DC.

Belkaoui, A. and A. Kahl (1978), Corporate Financial Disclosure in Canada, Research Monograph No. 1 of Canadian Certified General Accountants Association, Vancouver.

Bowers, D. (1973), “A review of Rensis Likert's, Improving the Accuracy of P/L Reports and Estimating the Change in Dollar Value of the Human Organization," Michigan Business Review, Vol. 25.

Brummet, R.L., Flamholtz, E.G. and Pyle, W.C. (1968), "Human resource measurement a challenge for accountants", The Accounting Review, Vol. 18 No. 2, pp. 217-24.

Chow, C.W. and Wong-Boren, A. (1987), Voluntary Financial Disclosure by Mexican Corporations, The Accounting Review, Vol. LXII, No. 3, pp. 533-541.

Conner, (1991), "A Historical Comparison of Resource-Based Theory and Five Schools of Thought Within Industrial Organization Economics: Do We Have a New Theory of the Firm?," Journal of Management, Vol. 17, No. 1, pp. 121-54.

Cooke, T. E. (1989), Disclosure in the Corporate Annual Reports of Swedish Companies, Accounting and Business Research, Vol. 19, No. 74, pp. 113-124. 
Cooke, T. E. (1991), An Assessment of Voluntary Disclosure in the Annual Reports of Japanese Corporations, The International Journal of Accounting, Vol. 26, pp. 174-189.

Flamholtz, E.G. and Main, E.D. (1999), "Current issues, recent advancements and future directions in human resource accounting", Journal of Human Resource Costing and Accounting, Vol. 4, No. 1, pp. 11-20.

Guthrie, J., Petty, R., Yongvanich, K. and Ricceri, F. (2004), "Using content analysis as a research method to inquire into intellectual capital reporting", Journal of Intellectual Capital,Vol. 5 No. 2, pp. 282-93.

Haniffa, R.M. and Cooke, T.M. (2002), Culture, Corporate Governance and Disclosure in Malaysian Corporations, Abacus, Vol. 38, No. 3, pp. 317-349.

Heckmian, J.S. and Jones, C.H. (1967), "Put people on your balance sheet", Harvard Business Review, Vol. 45, pp. 105-13.

Hossain et al. (1995), Financial Management (in Bengali), Angel Publications: Dhaka.

Hossain, M. A., (1998), 'Disclosure of Financial Information in Developing Countries: A Comparative Study of Non-Financial Companies in India, Pakistan and Bangladesh', Ph.D. Dissertation, School of Accounting and Finance, Victoria University of Manchester, UK, July-1998.

Hossain, M. (2008), The Extent of Disclosure in Annual Reports of Banking Companies: The Case of India, European Journal of Scientific Research, ISSN 1450-216X Vol.23 No.4 (2008), pp.659-680.

Hossain, M. S., (2010), Financial Reporting Practices of Listed Pharmaceuticals Companied in Bangladesh, Unpublished PhD Dissertation, National University, Bangladesh.

Hossain, M. A., Islam, K. S. and Andrew, J., (2006), Corporate Social and Environmental Disclosure in Developing Countries: Evidence from Bangladesh, Asian Pacific Conference on International Accounting Issues, Hawaii, October-2006.

Hossain, M., Khan, A. R., Yasmin, I. (2004), "The Nature of Voluntary Disclosures on Human Resource in the Annual Reports of Bangladeshi Companies" Dhaka University Journal of Business Studies, 25(1) pp. 221-231.

Inchausti, B. G. (1997), The Influence of Company Characteristics and Accounting Regulations on Information Disclosed by Spanish Firms, The European Accounting Review, Vol. 1, No. 1, pp. 45-68.

Islam, MA \& Deegan, C 2010, 'Social Responsibility Disclosure Practices: Evidence from Bangladesh', Certified Accountants Educational Trust, The Association of Chartered Certified Accountants, 29 Lincoln's Inn Fields, London WC2A 3EE.

Ismail, T. H., (2002), An Empirical Investigation of Factors Influencing Voluntary Disclosure of Financial Information on the Internet in the GCC Countries, Working Paper Series, Social Sciences Research Network, July 2002.

Khan, M.H.U.Z. and Ali, M.M. (2010), “An empirical investigation and users' perceptions on intellectual capital reporting in banks: evidence from Bangladesh", Journal of Human Resource Costing \& Accounting, Vol. 14 No. 1, pp. 48-69.

Khan, M.H. \& Khan, M.R., (2010), 'Human capital disclosure practices of top Bangladeshi companies', Journal of Human Resource Costing \& Accounting, Vol. 14, No. 4, pp. 329 349.

Lang, M.H. \& Lundholm, R.J. (1993), 'Cross-sectional Determinants of Analyst Ratings of Corporate Disclosures', Journal of Accounting Research, Vol. 31, No. 2, pp. 246-271. 


\section{MInstitute ${ }^{\text {Mink }}$}

International Journal of Accounting and Financial Reporting ISSN 2162-3082

Liebowitz, J. and Wright, K. (1999), “Does measuring knowledge make 'cents': expert systems with applications", Vol. 17 No. 2, pp. 99-103.

Li, J., Pike, R. \& Haniffa, R. (2006), 'Intellectual Capital Disclosures in Corporate Annual Reports: A European Comparison', Working Paper No. 06/24, School of Management, Bradford University, July 2006.

Likert, R. (1967), The Human Organization: Its Management and Value,McGraw-Hill, New York, NY.

Mamun, S.A.A. (2009), 'Human Resource Accounting (HRA) Disclosure of Bangladeshi Companies and Its Association with Corporate Characteristics', BRAC University Journal, Vol. V1, No. 1, pp. 35-43.

McGregor, J., Tweed, D. and Pech, R. (2004), "Human capital in the new economy: devil's bargain?", Journal of Intellectual Capital, Vol. 5 No. 1, pp. 153-164.

Moore, R. (2007), Measuring how 'human capital' appreciates in value over time. Plant Engineering, Vol. 61, No. 4, pp. 29.

Murthy, V \& Abeysekera, I., (2007), 'Human capital value creation practices of software and service exporter firms in India', Journal of Human Resource Costing and Accounting, Vol. 11, No. 2, pp. 84-103.

Olsson, B. (2001), 'Annual reporting practices: information about human resources in corporate annual reports in major Swedish companies', Journal of Human Resource Costing and Accounting, Vol. 6 No. 1, pp. 39-52.

Owusu-Ansah, S. (1998), 'The Impact of Corporate Attributes on The Extent of Mandatory Disclosure and Reporting by Listed Companies in Zimbabwe', The International Journal of Accounting, Vol. 33, No. 5, pp. 605-631.

Porwal, L. S. (1993), Accounting Theory, Second Edition, Tata McGraw-Hill Publishing company, New Delhi.

Raffourneir, B. (1995), The Determinants of Voluntary Financial Disclosure by Swiss Listed Companies, European Accounting Review, Vol. 4, No. 2, pp. 261-280.

Rao, V.S.P. (2005), Human Resource Management: Text and Cases. (2nd ed). New Delhi: Excel Books.

Ripoll, G. Labatut, (1994), "La contabilidad dey los costes de recursos humanos: implicaciones contables y fiscals de su," Técnica Contable, January (1994)

Roslender, R. and Dyson, J.R. (1992), "Accounting for the worth of employees: a new look at an old problem", British Accounting Review, Vol. 24, pp. 311-29.

Royal, C. and O'Donnell, L. (2005), "Embedding human capital analysis in the investment process: a human resources challenge", Asia Pacific Journal of Human Resources, Vol. 43 No. 1, pp. 117-36.

Royal, C. and O'Donnell, L. (2008), "Emerging human capital analytics for investment processes", Journal of Intellectual Capital, Vol. 9 No. 3, pp. 367-79.

Sackman, A., Flamholtz, E. G., Bullen, M. L. (1989) "Human Resource Accounting; A State-of-the-Art Review", Journal of Accounting Literature, Vol. 8, pp. 235-264.

Schultz, T.W. (1961), "Investment in Human Capital". American Economic Review.51, March Pp.1-17

Shirley, C. et al., (2009), 'Corporate Social Responsibility Reporting in Malaysia: An 
Analysis of Website Reporting of Second Board Companies Listed in Bursa Malaysia', SEGI Review, Vol. 2, No. 2, pp. 85-110, http://www.onlinereview.segi.edu.my/chapters/ vol2_chap8.

Silva, W. M., and Christensen T. E., (2004), Determinants of Voluntary Disclosure of Financial Information on the Internet by Brazilian Firms, doi: papers.ssrn.com/so13/ papers.cfm?abstract_id $=638082$

Spero (1979), The Extent of Voluntary Disclosure of Financial Information in Three European Capital Markets: An Explanatory Study, Doctoral Dissertation, Harvard University.

Spiegel, M.M. and Yamori, N. (2004), Determinants of Voluntary Bank Disclosure: Evidence from Japanese Shinkin Banks, CESifo Working Paper No. 1135, Category 6: Monetary Policy and International Finance, February 2004, Presented at Venice Summer Institute, Workshop on Economic Stagnation in Japan, July 2003.

Stewart, T.A. (1994), "Your company’s most valuable asset", Fortune, Vol. 130 No. 7, pp. 68-69.

Subbarao, A.V. \& Zeghal, D. (1997), 'Human resources information disclosure in annual reports: an international comparison', Journal of Human Resource Costing and Accounting, Vol. 2, No. 2, pp. 53-73.

Sutthachai, S. and Cooke, T.E. (2009), An Analysis of Thai Financial Reporting Practices and the Impact of the 1997 Economic Crisis, ABACUS, Vol. 45, No. 4, doi: 10.1111/j.1467-6281.2009.00285.x.

Sveiby, K.E. (1997), The New Organizational Wealth and Measuring Knowledge- Based Assets, Berrett- Koehler, San Francisco, USA.

Thompson, G.D. (1998), "Cultural capital and accounting", Accounting, Auditing and Accountability Journal, Vol. 12, No. 4, pp. 394-412.

Ullah, M. H. (2013), Accounting and Reporting Practices of Islamic Banks in Bangladesh, Unpublished M. Phil Thesis, University of Chittagong, Bangladesh.

Uwalomwa, U. (2011), An Empirical Investigation of the Association between Firms' Characteristics and Corporate Social Disclosures in the Nigerian Financial Sector, Journal of Sustainable Development in Africa, Vol. 13, No.1, ISSN: 1520-5509, Clarion University of Pennsylvania, Clarion, Pennsylvania.

Wallace, R. S. O. (1987), Disclosure of Accounting Information in Developing Countries: A Case Study of Nigeria, Doctoral Dissertation, University of Exeter, Devon.

Wallace, R. S. O., and Naser, K. (1995), Firm Specific Determinants of the Comprehensiveness of Mandatory Disclosure in the Corporate Annual Reports of Firms Listed on the Stock Exchange of Hong Kong, Journal of Accounting and Public Policy, Vol. 14, No.4, pp. 311-368.

Watson, A., Shrives, P. and Marston, C. (2002), Voluntary Disclosure of Accounting Ratios in the UK, British Accounting Review, Vol. 34: pp. 289-313.

Wyatt, W. (2001), "HR practices as leading indicators of financial success", Watson Wyatt 1999-2001 Human Capital Index Survey Press Release, Worldwide, October 29. 